\title{
Network meetings - access to specialist knowledge and mediation of social support for patients with primary brain tumours and their families - a participatory action research project
}

\author{
Pia Riis Olsen \\ From The European Academy of Nursing Science EANS Summer Conference \\ Barcelona, Spain. 8-9 July 2015
}

\section{Background}

A malignant brain tumour often causes cognitive impairment. This affects both patients and families. Compared to other cancer patients, studies show that they are significantly more in need of social support and help for everyday activities.

A network focused approach has been shown to facilitate the involvement of a supportive social network around the patient and the family, which can assist them in keeping their world together.

\section{Aims}

To develop and implement a research based service that will promote mobilization of a supportive social network for patients with primary brain tumours and their families.

\section{Methods}

Participatory action research involved parallel processes of focus group interview, individual interviews with patients and usually their spouses, and group sessions of cooperative inquiry, education and interaction between the researcher and a group of ten clinical nurses. This group of clinical nurses met with the researcher every quarter to reflect on findings, experiences and practical issues in offering patients the service of personal network meetings.

\section{Results}

The study is estimated to finish in 2015. All interviews are completed and are currently being analysed. The group of nurses has been trained in planning and leading network

Correspondence: piaolsen@rm.dk

Department of Oncology, Aarhus University Hospital, Aarhus, Denmark meetings. At present the service is being piloted in the department and the group of nurses acts as implementation agents in their clinics. Early presentation of individualised network meetings is welcomed as an opportunity and accepted by some patients and relatives. The service is feasible in practice.

\section{Conclusion}

The interactive approach in action research has supported the implementation of the complex service: network meetings. This service has potential in other nursing areas.

Published: 8 October 2015

doi:10.1186/1472-6955-14-S1-S4

Cite this article as: Olsen: Network meetings - access to specialist knowledge and mediation of social support for patients with primary brain tumours and their families - a participatory action research project. BMC Nursing 2015 14(Suppl 1):S4.

Submit your next manuscript to BioMed Central and take full advantage of:

- Convenient online submission

- Thorough peer review

- No space constraints or color figure charges

- Immediate publication on acceptance

- Inclusion in PubMed, CAS, Scopus and Google Scholar

- Research which is freely available for redistribution

Submit your manuscript at www.biomedcentral.com/submit 